\title{
Analyzing the Relationship, Distribution of Tree Species Diversity, and Above-Ground Biomass on the Chitwan-Annapurna Landscape in Nepal
}

\author{
Shiva Pokhrel (iD ${ }^{1}$ and Chungla Sherpa ${ }^{2}$ \\ ${ }^{1}$ International Centre for Integrated Mountain Development, Kathmandu, Nepal \\ ${ }^{2}$ Forest Research and Training Center, Ministry of Industry, Tourism, Forest and Environment, Gandaki Province, \\ Pokhara, Nepal \\ Correspondence should be addressed to Shiva Pokhrel; shiva.pokhrel@icimod.org
}

Received 31 December 2019; Revised 22 October 2020; Accepted 4 November 2020; Published 21 November 2020

Academic Editor: Ahmad A. Omar

Copyright (c) 2020 Shiva Pokhrel and Chungla Sherpa. This is an open access article distributed under the Creative Commons Attribution License, which permits unrestricted use, distribution, and reproduction in any medium, provided the original work is properly cited.

\begin{abstract}
Forests provide numerous ecosystem goods and services. Their roles are considered as important for both climate mitigation and adaptation program. In Nepal, there are significant forest resources which are distributed in different regions; however, the studies on the spatial tree species distribution and the above-ground biomass and their relationship at the landscape level have not been well studied. This study aims to analyze the relationship, distribution of tree species diversity, and above-ground biomass at a landscape level. The data used for this study were obtained from the Forest Research and Training Center of Nepal, International Centre for Integrated Mountain Development (ICIMOD), and Worldwide Wildlife Fund (WWF-Nepal). The landscape has a mean of 191.89 tons ha ${ }^{-1}$ of the above-ground biomass. The highest amount of the above-ground biomass measured was 650 tons ha ${ }^{-1}$ with 96 individual trees, and the least was 3.428 tons ha $^{-1}$. The measured mean height of the tree was $11.77 \mathrm{~m}$, and diameter at breast height $(\mathrm{DBH})$ was $18.59 \mathrm{~cm}$. In the case of the spatial distribution of the above-ground biomass, plots distributed at the middle altitude range greater than 900 meters above sea level (m. a. s. l) to 3000 meters above sea level taking more amount of the above-ground biomass (AGB). Similarly, the highest plot-level Shannon diversity index $\left(H^{\prime}\right)$ was 2.75 with an average of 0.96 at the middle altitude region followed by the lower region with an average of 0.89 and least 0.87 at a higher elevation. Above-ground biomass $\left(R^{2}=0.48\right)$ and tree height $\left(R^{2}=0.506\right)$ significantly increased with increasing elevation up to a certain level increased of elevation. Diameter at breast height $(\mathrm{DBH})$ showed significance $\left(R^{2}=0.364\right)$ but small increase with increasing elevation, while the relationship among tree species diversity index, above-ground biomass, and elevation showed a weak and very weak positive relationship with $R^{2}=0.018$ and $R^{2}=0.002$, respectively. Based on the overall results, it is concluded that elevation has some level of influence on the forest tree diversity and above-ground biomass. The finding of this study could be useful for landscape-level resource management and planning under various changes.
\end{abstract}

\section{Introduction}

Forests have a significant function in the world climate system by changing the concentration of carbon dioxide in the atmosphere [1]. As regards important services, forests and trees play a vital role in the preservation of ecosystems by sustaining the quality of goods and services they produce during their functioning. Forests are the most important natural stores of biomass and sink and store carbon than any other terrestrial ecosystem and store more carbon than the world's oil reserves; they also continually remove carbon from the atmosphere through photosynthesis that alters atmospheric carbon to organic matter due to which the relationship between biodiversity and carbon cycle has become an important consideration in an international effort for conserving the natural ecosystem [2]. The significant involvement of forest ecosystem in carbon conservation and sequestration has been playing a vital role in 
the present global climate change context, and therefore, forest is kept in the center of climate change mitigation strategies [3,5]. Pan et al. [4] stated that $40 \%$ of global terrestrial carbon is contained in the living forest biomass. The quantity of above-ground biomass in a forest governs the prospective volume of carbon that can be added to the atmosphere or sequestered on the land when forests are accomplished for achieving emission goals [6]. The amount of above-ground biomass produced differs from places to places, and the relationship between above-ground biomass and species diversity has been discoursed for many years [7-9]. In this regard, regular inventory and monitoring are considered as an important means to understand the structure, diversity, above-ground biomass of different habitats, and vegetation type support for achieving international agreements [10]. In tropical forests, variation may occur due to regional differences in climate, species diversity, stem density, canopy height, stem size distribution, edaphic circumstances, geography, and disturbance history $[1,10-16]$. Likewise, changes in several environmental variables along with a change in altitude could also influence the amount of above-ground biomass of that particular species that is found in a particular area. Therefore, climate variables are considered as the greatest importance where altitudinal gradient and species richness are concerned [17]. Furthermore, there is a significant relationship between species richness and ecosystem productivity [18-20]. Generally, the higher productivity is associated with the greater number of individual and/or more total biomass of tree species in a forest ecosystem [21]. Climatic variables, mainly temperature and precipitation, having influencing ability on primary productivity resemble species richness [22, 23]. Hence, altitudinal gradients and species richness are among the most weighted prevailing natural trials for testing environmental and evolutionary retorts of biota to environmental changes. Spatial variability information on forest above-ground biomass, species diversity distribution, and its allotment along the altitudinal gradients could provide better spatial forest management plan considering the multiple benefits of the forest ecosystem for climate mitigation and forest resource management.

Globally, around $9 \%$ of the total number of tree species accounting around 8000 individual species are under the threats of extension due to declining the forest and threats of climate change. Tropic which is rich in biodiversity has been facing double impacts from climate change and anthropogenic pressure [24]. The interrelation between climate change, biodiversity, and decreasing forest area has been observed in a different spatial scale ranging from local, regional, and at a global level. Nepal, a small South Asian nation, covers only $0.1 \%$ of the global land surface but homes to 136 ecosystem types with about $2 \%$ of flowering plants, $6 \%$ of the bryophytes of world flora, and $3 \%$ of the pteridophytes. Eight types of species are assumed to be extinct, one species is threatened, seven types of species are vulnerable, and 31 species tumble under the IUCN rare species groups [25, 26]. The Chitwan-Annapurna Landscape (CHAL), a part of the Sacred Himalayan Landscape, is located in central Nepal with a rich biodiversity landscape and occupies an area of 32,057 square kilometers [27]. The physiographic regions of the landscape range from subtropical in lowland to alpine in highland. The huge variation in elevation, climate, and topography has supported different types of forest in the landscape which range from tropical mixed deciduous forest dominated by Shorea robusta in Siwaliks to Schima-Castanopsis forests in the midhills and subalpine-alpine scrub vegetation comprising Juniperus species and Rhododendron species in the high mountains and high Himal areas [27]. The spatial fieldmeasured forest-tree diameter at breast height and tree height data from the forest plot area could be utilized to calculate the forest above-ground biomass, and later, this could supplement for the evaluation of the amount of carbon that a particular forest ecosystem stored [28, 29]. Similarly, at the same time, information collected during the plot-level survey also supplements the particular species which exist in that plot, and this can be utilized for the tree's species diversity and forest structure assessment. This study uses data collected from various plots of equal size that is a spatially distributed thought study area. The relation between aboveground biomass, species diversity, elevation, and stand parameters such as DBH and height was assessed using standard statistical tools and methods.

1.1. Study Area. Chitwan-Annapurna Landscape is the part of high biodiversity-rich landscapes of the greater Himalayan landscape, located at $27^{\circ} 35^{\prime \prime}$ and $29^{\circ} 33^{\prime \prime}$ N latitude and $82^{\circ} 88^{\prime \prime}$ and $85^{\circ} 80^{\prime \prime} \mathrm{E}$ longitude in Nepal, which envisaged during the development of biodiversity vision in Nepal [27]. The landscape covered 32,057 square kilometers of the 19 districts of central Nepal. Eight major river systems namely: Kali Gandaki, Seti, and Madi, Marsyangdi, Daraundi, Budi Gandaki, Trishuli, Rapti and their tributaries. The landscape also covers the full or partial part of six protected areas and their buffer zones. This landscape links the ecologically unique ecoregion between north and south of Nepal through terrestrial connectivity via exiting different forest regimes: government-managed, community, protection, leasehold, and buffer zone community forest. Geographically, 11.4 percentage is located in the Siwalik region, 37.8 percentage in the midhills, and 50.8 percentage in the mountain region with $200 \mathrm{~m}$ to $8,091 \mathrm{~m}$ altitudinal variation with forest area distributed on less than $4000 \mathrm{~m}$ (Figure 1).

The landscape has varied climate which ranges from subtropical humid in the lowlands at Siwaliks to cold alpine semidesert in the trans-Himalayan zone [27].

\section{Materials and Methods}

The main materials used for this study were field-collected data, geospatial data layer, and sets of software that are required for the statistical and spatial analysis. $30 \mathrm{~m}$ SRTM digital elevation model developed by NASA, geodatabase consisting of study area shapefile, and 20210 forest cover from the ICIMOD were used for the elevation determination and identification of the forest cover area in the landscape. The lowest plot elevation from the forest 
area was $237 \mathrm{~m}$, and higher elevation was $3484 \mathrm{~m}$ from mean sea level (MSL). Forest inventory data at the plot level were collected from FRTC-Nepal, ICIMOD, and WWF-Nepal representing this entire stratum. These institutes have collected those data by using a stratified random sampling method with a circular plot of $500 \mathrm{~m}^{2}$ and a radius of $12.62 \mathrm{~m}$ following IPCC standard guidelines [30]. Generally, out of various sampling techniques, stratified random sampling has been extensively used for forest biomass inventory as it gives more accurate estimation [31]. During the fieldwork, they have collected different information such as tree height, diameter at breast height $(\mathrm{DBH})$ measured at 1.3 meters above $10 \mathrm{~cm}$, tree species (local name and scientific name), and plot spatial information. A total of 384 plot data collected from 2010 to 2015 in different physiographic regions were processed and analyzed for measuring the spatial distribution of tree diversity and above-ground biomass; further data from 90 plots representing different elevations were used for statistical analysis along the ChitwanAnnapurna Landscape.

\section{Biomass Stock Mapping and Modeling}

3.1. Biomass Stock Calculation. Generally, above-ground biomass is assessed from volumetric and structural dimensions of the trees for which diameter at breast height (DBH) and height of the tree are taken as major variables. In lack of species-specific biomass equation of the trees, species-specific volume equations established by Sharma and Pukkala [32] were used to measure the above-ground biomass of standing tress. The overall stem volume of single trees was derived from field-measured $\mathrm{DBH}$ and tree height using the relationship in the following form [32]:

$$
\begin{array}{r}
\ln (V)=a+b * \ln (\mathrm{DBH})+c * \ln (\mathrm{Ht}), \\
\text { equation }(1)-\text { allometric volume equation, }
\end{array}
$$

where $\ln$ is the natural logarithm to the base $2.71828, V$ is the total stem volume with bark in $\mathrm{m}^{3}$, to get the volume in cubic meters, the estimate is to be divided by $1000, \mathrm{DBH}$ is the diameter at breast height in centimeter $(\mathrm{cm}), \mathrm{Ht}$ is the tree height in meter, and $a, b$, and $c$ are model parameters.

The estimated parameter value of $a, b$, and $c$ for different species and wood density of the foremost tree species are specified in Table 1.

The obtained volume was multiplied with dry wood density (specific gravity) of the species to obtain an air-dry bulk of trunk biomass [33] by applying equation (2). Species initiate in the landscape, and correspondingly, other species and their values were also kept, and volume was derived accordingly as shown in equation (1).

$$
\begin{aligned}
& \text { Stem biomass }=\text { stem volume } * \text { wood density, } \\
& \text { equation }(2)-\text { calculation of stem biomass. }
\end{aligned}
$$

Due to the nonappearance of conventional biomass associations of diverse tree components of separate tree species of sample forest types, this analysis used the relationship established by Sharma [34] for a solitary species of analogous forest types of Nepal which was later implemented by Shrestha and Singh [35]. The biomasses of branches and leaves (foliage) were estimated to be $42 \%$ and $8 \%$ of the stem biomass, respectively [34], to calculate the total biomass of trees.

Total AGB = stem biomass + branch biomass + foliage biomass,

$$
\text { equation (3) - AGB. }
$$

3.2. Measuring Forest Tree Species Diversity. This study relates the Shannon diversity index $\left(H^{\prime}\right)$ as a compute of diversity among the trees in different measured plots in the CHAL area to measure the diversity of the tree species across the landscape. This index grabs jointly species wealth and species lushness on interpretation:

$$
H^{\prime}=-\sum_{i=1}^{S} p_{i} \ln p_{i}
$$

where $S$ equals number of species, $p_{i}$ equals the ratio of individual of species I divided by all individuals $N$ of all species, and $\ln$ is the natural logarithm to the base. The Shannon diversity index ranges usually from 1.5 to 3.5 and infrequently reaches 4.58 [36].

\subsection{Mapping the Spatial Distribution of Above-Ground Bio-} mass and Tree Diversity. Spatial variations are common in many ecological variables and have common characteristics and properties in their occurrence. For this reason, topographical position of examination should be stated for reflection on concurrently in totaling a belonging value to describe patterns of quantitative distribution of such ecological parameters [37]. In such circumstances, the geostatistical technique could contribute to analyze and estimate the variation of the spatially dependent variable based on the properties. Based on the principle of nearer observation, sample values are more likely to be nearer than the samples of at a distance one.

Many earlier studies on metrology, mining, geology, and different branches of ecology have used this approach for identifying spatial variations/distribution [38-42]. For this study, a geostatistical approach was used to extrapolate the spatial distribution of the Shannon diversity index and above-ground measure biomass that is measured at the plot level [43-46]. This technique was presented by Matheron in 1963 and commonly applied to determine the consequence of spatial conglomeration in forestry sectors and environmental variable analysis also. Equation (5) was deployed for this calculation:

$$
\left(S_{0}\right)=\sum_{i=1}^{N} \lambda_{i} Z\left(S_{i}\right)
$$

where $Z\left(S_{i}\right)$ indicates the calculated value of the $i$ location; $\lambda_{i}$ indicates the indefinite value-weight for the measured 


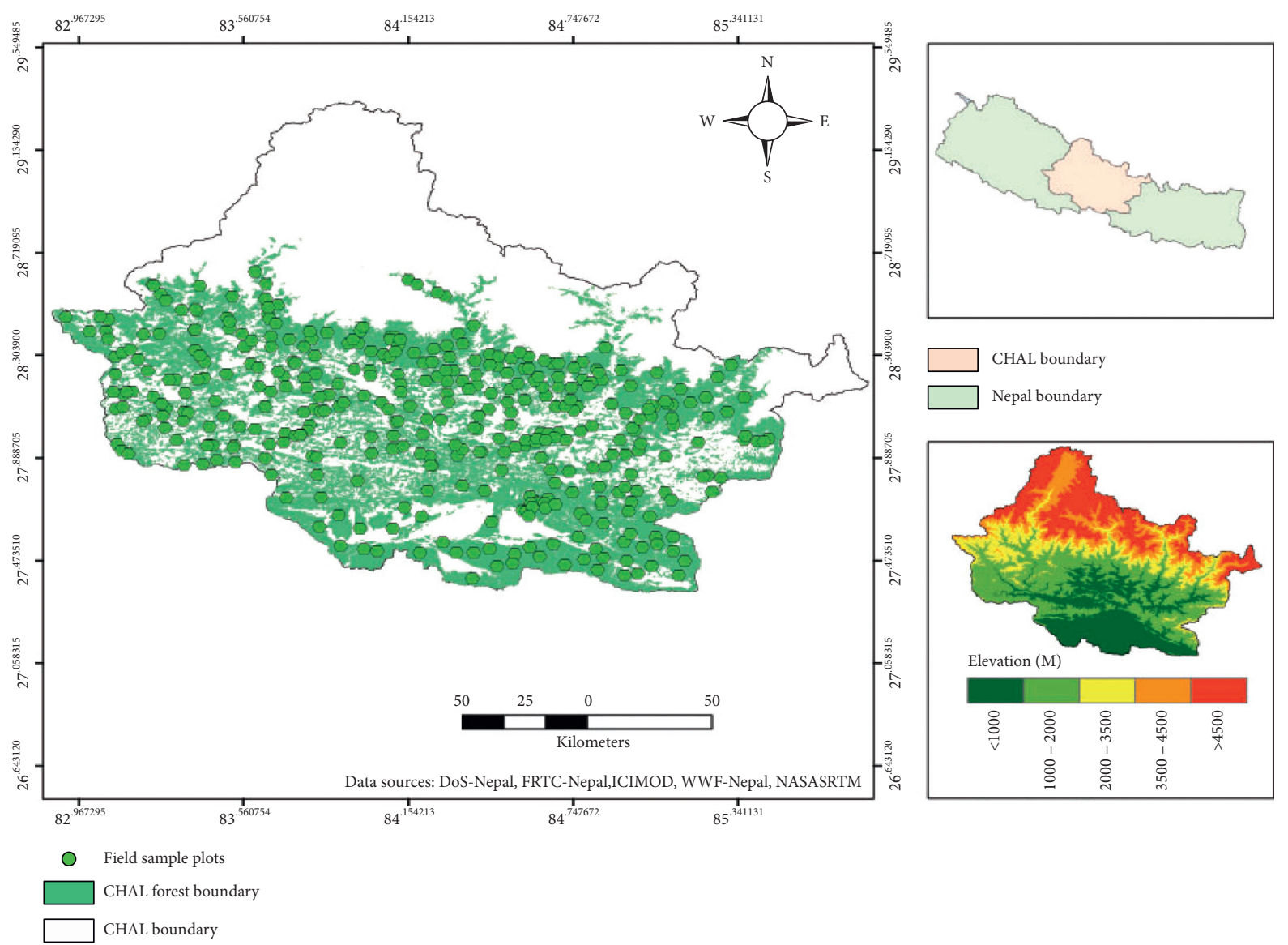

Figure 1: Map showing the study area with the field sample plot location.

value on the $i$ location; $S_{0}$ indicates the predication location; and $N$ indicates the number of calculated values.

\section{Results}

4.1. Above-Ground Biomass and Forest Tree Species Diversity. Above-ground biomass stock of separate trees was calculated species-wise in kilograms; formerly, total biomass of trees calculated in the sampling plots was transformed into ton, and biomass stock ton per hectare was then estimated by extrapolating the biomass stock from the sample plot of $500 \mathrm{~m}^{2}$ to hectare (ha). The average above-ground biomass measured was 191.89 tons $^{-1} \mathrm{a}^{-1}$ for the Chitwan-Annapurna Landscape. The largest amount of tree above-ground biomass measured was 650 tons per hectare with 96 individual trees in a plot of broadleaved forest dominated by Shorea robusta, while the least amount of biomass measured was 3.428 tons per hectare in a forest dominated by Pinus species and Schima wallichii with 13 individuals. Mean diameter at breast height $(\mathrm{DBH})$ and height of stems in the study were $18.59 \mathrm{~cm}(\mathrm{SD}=6.21)$ and $11.77 \mathrm{~m}(\mathrm{SD}=4.45)$. The highest amount of biomass was found within a tall tree greater than $15 \mathrm{~m}$ height accounting for approximately $90 \%$ of the biomass across all of the plots. Similarly, for diameter at breast height $(\mathrm{DBH})$, the greatest biomass was observed on a tree having DBH greater than $45 \mathrm{~cm}$ in all plots. Similarly, in this study, it was observed that above-ground biomass at the middle altitudinal zone ranging from $902 \mathrm{~m}$ amsl to $3000 \mathrm{~m}$ MASL takes the largest amount.

Altogether, 160 different tree species were recorded from the plot-level survey data from different altitudinal ranges in the CHAL area. The highest number of different individual tree species recorded is 29 in a plot, and the least is 1 species which is only one species that exists in that plot. Regarding Shannon diversity index $\left(H^{\prime}\right)$, the highest calculated index value for the study area is 2.75 , and the least is 0 , where there is no diversity. In the case of altitudinal variation and tree species diversity, an average Shannon diversity index for different altitudinal zones was calculated based on the plot elevation location. The calculation shows the middle region expanding from 1000 to $2500 \mathrm{~m}$ has the largest average index value of 0.96 followed by a lower region below $1000 \mathrm{~m}$, which has 0.89 , and least in the upper region $2500-3500 \mathrm{~m}$ with 0.87 Shannon diversity index value. Figure 2 shows the spatial distribution of tree species calculated through the Shannon diversity index $\left(H^{\prime}\right)$. Shorea robusta seems to be the most dominant tree species in the lowland forest area. Likewise, Pinus species, Schima wallichii, Castanopsis indica, Alnus nepalensis, Quercus species, Lyonia ovalifolia, Eurya acuminata, Engelhardia spicata, Daphniphyllum himalense, and Rhododendron species dominancy have been observed with the change in certain elevations in the CHAL region. 
TABLE 1: Model parameters and wood density of major trees.

\begin{tabular}{lcccc}
\hline Species & $a$ & $b$ & $c$ & Wood density $\left(\mathrm{kg} / \mathrm{m}^{3}\right)$ \\
\hline Shorea robusta & -2.4554 & 1.9026 & 0.8352 & 880 \\
Syzygium cumini & -2.5693 & 1.8816 & 0.8498 & 770 \\
Schima wallichii & -2.7385 & 1.8155 & 1.0072 & 690 \\
Adina cordifolia & -2.5626 & 1.8598 & 0.8783 & 670 \\
Albizia sps. & -2.4284 & 1.7609 & 0.9662 & 425 \\
Alnus nepalensis & -2.7761 & 1.9006 & 0.9428 & 440 \\
Castanopsis indica & -2.3204 & 1.8507 & 0.8223 & 740 \\
Quercus & -2.3601 & 1.968 & 0.7469 & 594 \\
Rhododendron & -2.3204 & 1.8507 & 0.8223 & 640 \\
\hline
\end{tabular}

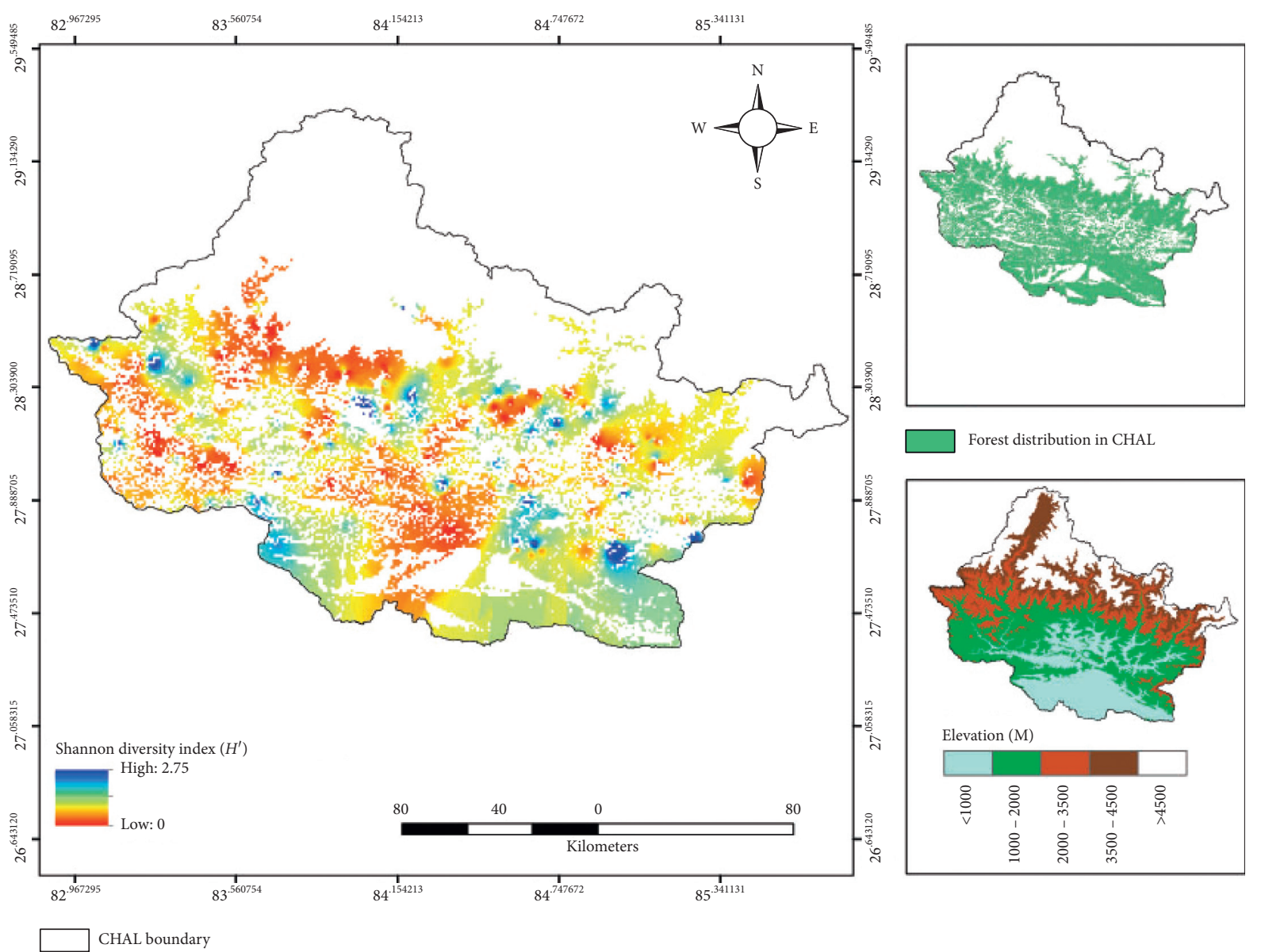

Figure 2: Tree species richness (Shannon diversity index $\left(H^{\prime}\right)$ ) distribution in CHAL.

4.2. Spatial Distribution of Above-Ground Biomass and Tree Species Diversity in CHAL. For mapping the above-ground biomass and diversity index value, geospatial techniquecalculated values were classified into different classes for AGB (four classes) representing the amount of biomass in ton $\cdot \mathrm{ha}^{-1}$. i.e., forest area having less than 10 ton $\mathrm{ha}^{-1}, 10-200$ ton $\mathrm{ha}^{-1}, 200-500$ ton $\mathrm{ha}^{-1}$, and greater than 500 ton ha ${ }^{-1}$, respectively. Similarly, for tree species diversity, the diversity index was classified into color pith values, namely, area having a high index value, medium index value area, and low index value area; resulting outputs are shown in Figures 2 and 3 .
4.3. Relationship between AGB, Elevation, Species Diversity, and Stand Parameters. Figure 4(a) shows the relationship of above-ground biomass with elevations. The maximum volume of the above-ground biomass remained detected in elevation between $900 \mathrm{~m}$ and $2500 \mathrm{~m}$ amsl. The analysis from the linear regression model $y=2.630 x+762.1$ was established to be the line of preeminent fit. A positive correlation $\left(R^{2}=0.48\right)$ was found between elevation and above-ground biomass, showing increases of above-ground biomass up to certain level of increase in elevation in the CHAL area. Ampere numeral of regression comparisons remained tried to infer the relationship among elevation and tree height; the best regression model 


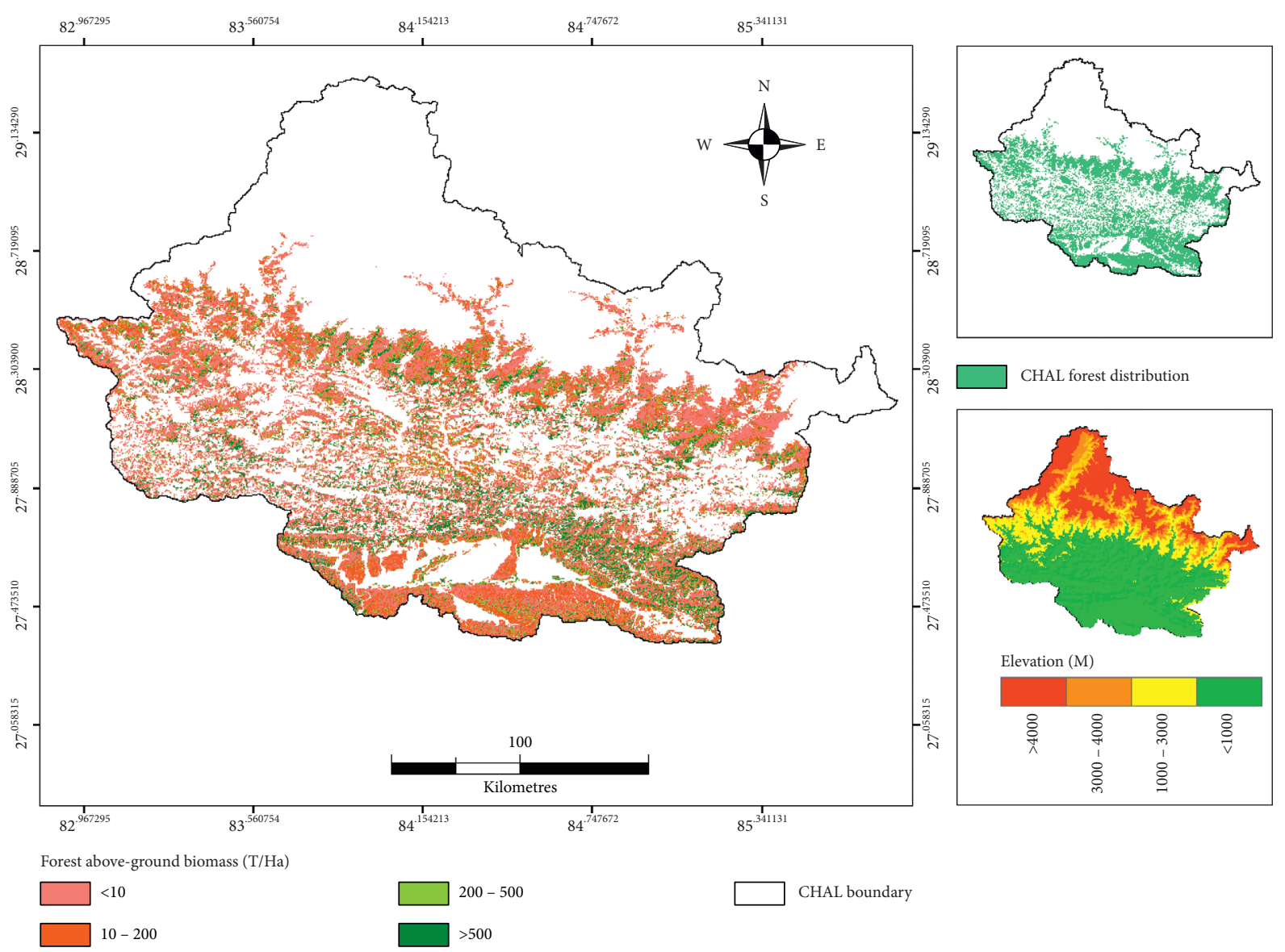

FIgURE 3: Map showing the spatial distribution of above-ground biomass in the CHAL area.

which found to be fitting was $y=148.9 x-411.0$ with a convincingly good correlation $\left(R^{2}=0.506\right)$ indicating the existence of a relationship between tree height and elevation as shown in Figure 4(b). Likewise, the linear regression model observed between average tree diameter and elevation also shows similar results with $y=0.005 x+11.56$ and $R^{2}=0.364$ (Figure $4(\mathrm{c})$ ). In the case of species diversity index and above-ground biomass, a very weak relationship has been observed as shown in Figure $4(\mathrm{~d})$. A linear regression model $y=0.020 x+7.874$ was found to be the best line of fit among various regression types, with $\left(\mathrm{R}^{2}=0.506\right)$ indicating the increase in tree height which means increasing above-ground biomass (Figure 4(e)). Likewise, the linear regression model between elevation and diversity index $y=193.7 x+991.5$ with $R^{2}=0.018$ was fit with indication of the confident feeble association amongst plot-tree species diversity and elevation. We relate a single-factor ANOVA for analyzing the effect of elevation on different variables, where elevation had some significant effects on various parameters, as shown in Table 2.

\section{Discussion}

The results of this study show a multifarious and variable association among elevation, tree species diversity, and forest above-ground biomass in CHAL forest areas. As numbers of factors play a significant role for variability of tree biomass in a forest ecosystem that may be because of elevation variation species composition, pattern of rainfall, forest types, age and structure of the forest stand, local site factors, and trees size $[47,48]$. In this present study, some plots having high tree species diversity had comparatively low biomass, and some plots with a minimum number of species had high above-ground biomass indicating near-no substantial relationship amid tree spices diversity and aboveground biomass. Some studies which were carried out in some parts of Nepal also found a very weak relationship between carbon stock and biodiversity [49-51].

However, in a few survey plots, a little positive correlation between tree species diversity and above-ground biomass was observed. Such a positive relationship is important in policy implementation for a program like REED+ which could co-benefit for biodiversity conservation as well as biodiversity hotspot identification for policymakers of local, provincial, and central level to implement a policy for resources management and planning development activities around their areas. The above-ground biomass that is estimated in this study is within the ranges that are found in a study carried out in different parts of Nepal [5, 49, 51-54]. The present biomass estimate demonstrates the high spatial variability of biomass storage within different forest areas. The survey plot with the highest above-ground biomass calculated contained more than 186 times the biomass of the 


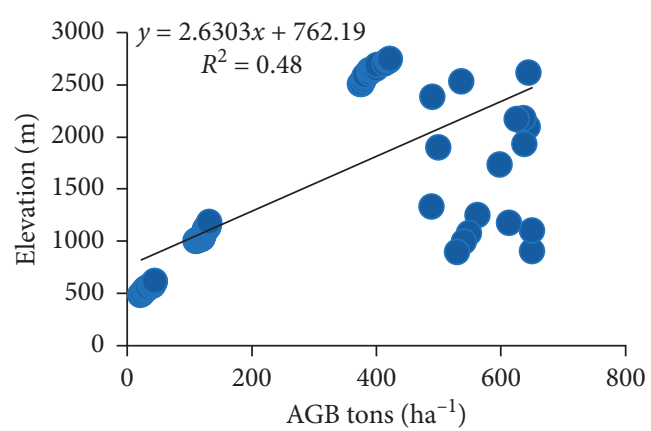

(a)

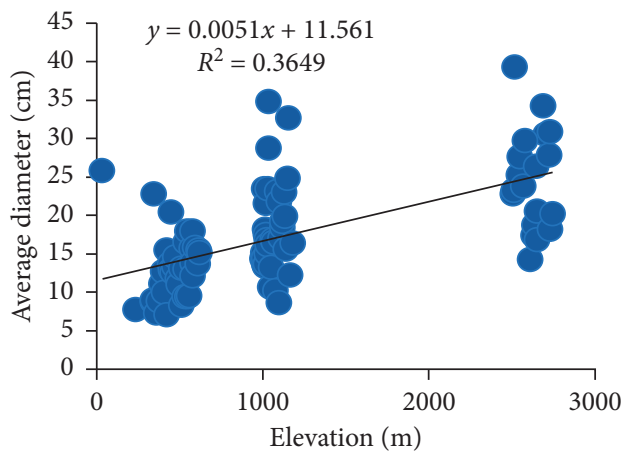

(c)

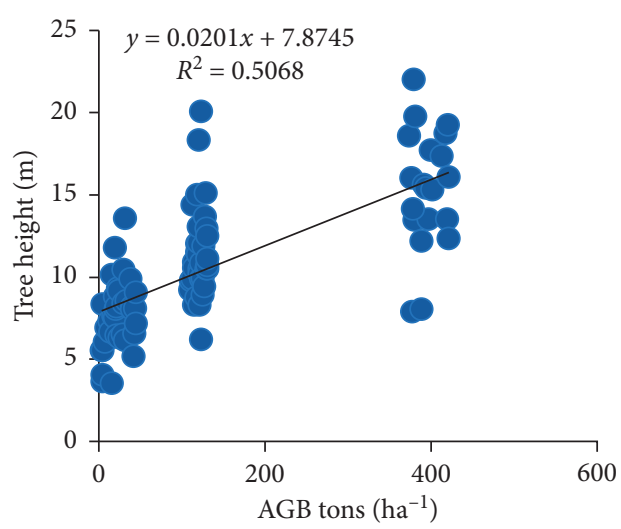

(e)

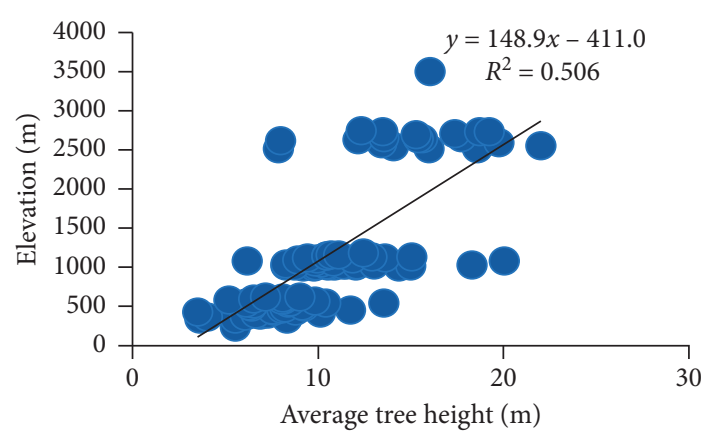

(b)

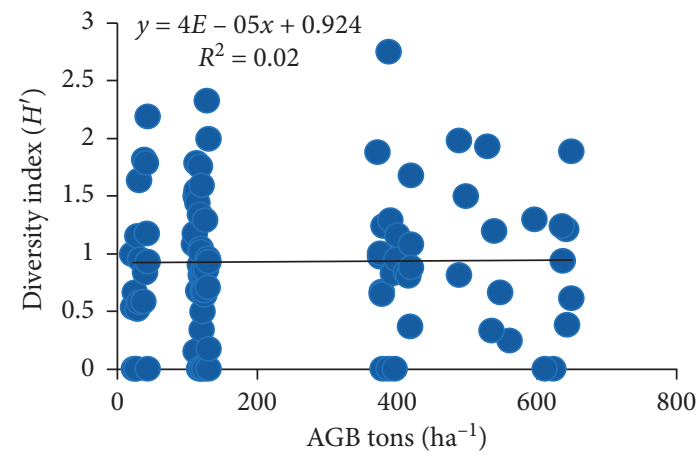

(d)

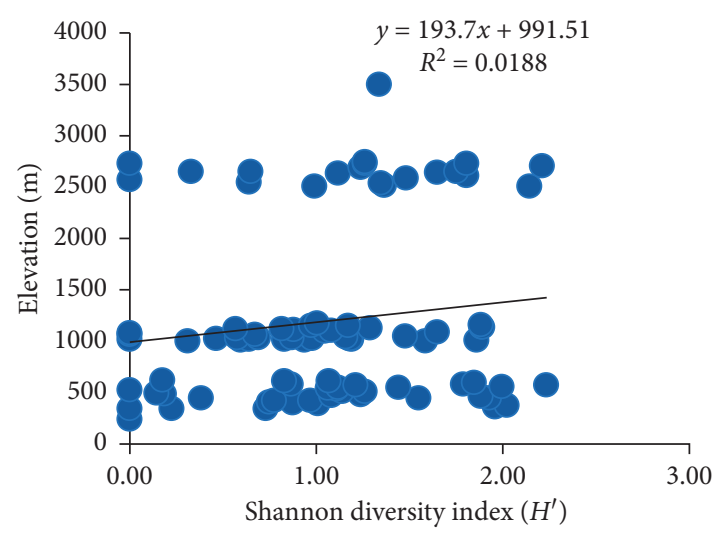

(f)

Figure 4: Relationship between AGB, elevation, species diversity, and stand parameters.

lowest calculated plot. Stand parameters such as tree height and $\mathrm{DBH}$ show positive correlation; a tree having larger DBH and bigger height has contributed more biomass in a plot. A similar finding was obtained by an earlier study [55-57].

Besides storing a large amount of biomass, the trees having bigger in both DBH and height size also provide greater ecosystem resilience and better sustainable doggedness of forest and places; therefore for carbon conservation/sequestration and such stand need better protection for climate change mitigation [58]. In the case of elevation-wise biomass distribution, it was observed that the elevations from the middle altitudinal zone take the larger portion of the above-ground biomass $\left(\right.$ ton $\cdot \mathrm{ha}^{-1}$ ), respectively. The higher altitudinal ranges take the lowest portion of the above-ground biomass. Based on the above-ground biomass calculation, the total aboveground biomass rank was ordered as middle altitude zone $(1000-2500 \mathrm{~m})>$ lower altitude (less than $1000 \mathrm{~m}$ ) $>$ higher altitude (2500-3500 m). In terms of tree species distribution, results of this study are important, both for nature conservation and planning for any land transformation activities/forest resource management plan, as the tree species is manifested differently in different forests along various measured plots from different elevations; higher diversity index is observed in the plot area which shares the physiographic zones or could have the ecotone or edge effects. 
TABLE 2: Analysis of variance (ANOVA) of elevation with respect to different variables.

\begin{tabular}{|c|c|c|c|c|c|c|}
\hline Above-ground biomass source of variation & SS & $\mathrm{d} f$ & $M S$ & $F$ & $P$ value & $F$ crit. \\
\hline $\begin{array}{l}\text { Between groups } \\
\text { Within groups } \\
\text { Total }\end{array}$ & $\begin{array}{l}64068370.77 \\
59688894.86 \\
123757265.6 \\
\end{array}$ & $\begin{array}{c}1 \\
178 \\
179\end{array}$ & $\begin{array}{l}64068371 \\
335330.9\end{array}$ & 191.0602 & $5.4 E-30$ & 3.89423 \\
\hline $\begin{array}{l}\text { Shannon diversity index source of variation } \\
\text { Between groups } \\
\text { Within groups } \\
\text { Total }\end{array}$ & $\begin{array}{c}93774717 \\
55873746 \\
1.5 E+08 \\
\end{array}$ & $\begin{array}{c}1 \\
178 \\
179 \\
\end{array}$ & $\begin{array}{r}93774717 \\
313897.5\end{array}$ & 298.7432 & $6.26 E-40$ & 3.894232 \\
\hline $\begin{array}{l}\text { DBH source of variation } \\
\text { Between groups } \\
\text { Within groups } \\
\text { Total }\end{array}$ & $\begin{array}{l}90709048 \\
56036815 \\
1.47 \mathrm{E}+08\end{array}$ & $\begin{array}{c}1 \\
178 \\
179\end{array}$ & $\begin{array}{c}90709048 \\
314813.6\end{array}$ & 288.1358 & $4.67 E-39$ & 3.89423 \\
\hline $\begin{array}{l}\text { Tree height source of variation } \\
\text { Between groups } \\
\text { Within groups } \\
\text { Total }\end{array}$ & $\begin{array}{l}92269591 \\
55875837 \\
1.48 E+08\end{array}$ & $\begin{array}{c}1 \\
178 \\
179\end{array}$ & $\begin{array}{l}92269591 \\
313909.2\end{array}$ & 293.9372 & $1.55 E-39$ & 3.89423 \\
\hline
\end{tabular}

\section{Conclusion}

Identifying tree species distribution and the amount of biomass that a particular forest stores at the landscape level are crucial to show forest ecosystem potential to climate change adaptation and mitigation program, as well as for biodiversity conservation. Our analysis reveals that some degree of variability subsists between elevation, above-ground biomass, and tree species diversity in the CHAL area. However, more research is obligatory to the causes of this variation with more spatial and temporal evidence information. Forest trees' above-ground biomass can be influenced by numbers of natural as well as anthropogenic factors. As some national-level assessment shows there is no significant change in forest cover in the CHAL area, especially in conservation areas over last few decades, however, as per informal reports/news, many parts of the landscape have been facing anthropogenic pressure via unscientific expansion of rural road, resettlements, urban expansion, and other land transformation activities which would directly influence the tree aboveground biomass and species distribution. Looking at present global climate change issues and the role of the forest ecosystem, the above-ground biomass and tree diversity in the landscape could play significant positive roles in the long-term stability and resilience of both humans and the ecology of this landscape.

\section{Data Availability}

The datasets generated and/or analyzed during the current study are available from the corresponding author upon reasonable request.

\section{Disclosure}

The views and interpretations in this publication are those of the authors. They are not necessarily attributable to ICIMOD and FRTC-Pokhara and do not imply the expression of any opinion by the ICIMOD concerning the legal status of any country, territory, city, or area of its authority or concerning the delimitation of its frontiers or boundaries or the endorsement of any product.

\section{Conflicts of Interest}

The authors declare no conflicts of interest.

\section{Acknowledgments}

ICIMOD gratefully acknowledges the support of its core donors: the governments of Afghanistan, Australia, Austria, Bangladesh, Bhutan, China, India, Myanmar, Nepal, Norway, Pakistan, Sweden, and Switzerland.

\section{References}

[1] UNFCCC, Report on a Workshop on Reducing Emissions from Deforestation in Developing Countries: Note by the Secretariat, United Nations Framework Convention on Climate Change, Rio de Janeiro, Brazil, 2006.

[2] FAO, The State of the World's Forests 2020: Forests-Biodiversity and People, FAO, Rome, Italy, 2020.

[3] J. Kishwan, R. Pandey, and V. K. Dadhwal, India's Forest and Tree Cover: Contribution as a Carbon Sink, Indian Council of Forestry Research and Education, Dehradun, India, 2009.

[4] Y. Pan, R. A. Birdsey, J. Fang et al., "A large and persistent carbon sink in the world's forests," Science, vol. 333, no. 6045, pp. 988-993, 2011.

[5] S. Pokhre, "Assessment of above ground biomass and fire risk zonation in selected forest areas of ludhikhola watershed, gorkha Nepal," Remote Sensing of Land, vol. 2, no. 1, pp. 47-64, 2018.

[6] S. L. Brown, P. Schroeder, and J. S. Kern, "Spatial distribution of biomass in forests of the eastern USA," Forest Ecology and Management, vol. 123, no. 1, pp. 81-90, 1999.

[7] C. M. Sharma, A. K. Mishra, R. Krishan, O. P. Tiwari, and Y. S. Rana, "Variation in vegetation composition, biomass production, and carbon storage in ridge top forests of high mountains of garhwal himalaya," Journal of Sustainable Forestry, vol. 35, no. 2, pp. 119-132, 2016.

[8] J. Szwagrzyk and A. Gazda, "Above-ground standing biomass and tree species diversity in natural stands of central Europe," Journal of Vegetation Science, vol. 18, no. 4, pp. 555-562, 2007. 
[9] R. J. Whittaker, "Meta-analyses and mega-mistakes: calling time on meta-analysis of the species richness-productivity relationship," Ecology, vol. 91, no. 9, pp. 2522-2533, 2010.

[10] UNEP/CBD, Global Strategy for Plant Conservation for a World Flora Online by 2020 United Nations Environmental Program/Convention for Biological Diversity, United Nations Environment Programme, Nairobi, Kenya, 2012.

[11] T. V. Con, N. T. Thang, D. T. T. Ha et al., "Relationship between aboveground biomass and measures of structure and species diversity in tropical forests of Vietnam," Forest Ecology and Management, vol. 310, pp. 213-218, 2013.

[12] T. V. Do, A. Osawa, and N. T. Thang, "Recovery process of a mountain forest after shifting cultivation in northwestern Vietnam," Forest Ecology and Management, vol. 259, pp. 1650-1659, 2010.

[13] D. Mohandass, A. C. Hughes, B. Mackay, P. Davidar, and T. Chhabra, "Floristic species composition and structure of a mid-elevation tropical montane evergreen forests (sholas) of the western ghats, southern India," Tropical Ecology, vol. 57, pp. 533-543, 2016.

[14] M. S. R. Murthy, S. Wesselman, and H. Gilani, Multi-Scale Forest Biomass Assessment and Monitoring in the Hindu Kush Himalayan Region: A Geospatial Perspective, International Centre for Integrated Mountain Development (ICIMOD), Kathmandu, Nepal, 2015.

[15] K. M. Ngo, B. L. Turner, H. C. Muller-Landau et al., "Carbon stocks in primary and secondary tropical forests in Singapore," Forest Ecology and Management, vol. 296, pp. 81-89, 2013.

[16] T. Urquiza-Haas, P. M. Dolman, and C. A. Peres, "Regional scale variation in forest structure and biomass in the yucatan peninsula, Mexico: effects of forest disturbance," Forest Ecology and Management, vol. 247, no. 1-3, pp. 80-90, 2007.

[17] V. Boucher-Lalonde, A. Morin, and D. J. Currie, "How are tree species distributed in climatic space? a simple and general pattern," Global Ecology and Biogeography, vol. 21, no. 12, pp. 1157-1166, 2012.

[18] R. T. Belote and G. H. Aplet, "Land protection and timber harvesting along productivity and diversity gradients in the northern rocky mountains," Ecosphere, vol. 5, no. 2, p. 17, 2014.

[19] R. A. Chisholm, H. C. Muller-Landau, K. Abdul Rahman et al., "Scale-dependent relationships between tree species richness and ecosystem function in forests," Journal of Ecology, vol. 101, no. 5, pp. 1214-1224, 2013.

[20] M. Jacob, C. Leuschner, and F. M. Thomas, "Productivity of temperate broad-leaved forest stands differing in tree species diversity," Annals of Forest Science, vol. 67, no. 5, p. 503, 2010.

[21] H. C. Keeling and O. L. Phillips, "The global relationship between forest productivity and biomass," Global Ecology and Biogeography, vol. 16, no. 5, pp. 618-631, 2007.

[22] C. M. McCain and J. A. Grytnes, "Elevational gradients in species richness," Encyclopedia of Life Sciences, John Wiley \& Sons, Hoboken, NJ, USA, 2010.

[23] D. Nogués-Bravo, M. B. Araújo, T. Romdal, and C. Rahbek, "Scale effects and human impact on the elevational species richness gradients," Nature, vol. 453, no. 7192, pp. 216-219, 2008.

[24] FAO, Global Forest Resources Assessment 2010 Main Report, FAO Food and Agriculture Organization of the United Nations, Rome, Italy, 2010.

[25] MFSC, National Biodiversity Action Plan, Ministry of Forests and Soil Conservation, HMG of Nepal, United Nations Development Programme, New York, NY, USA, 2000.
[26] NBSAP, National Biodiversity Strategy and Action Plan, Ministry of Forests and Soil Conservation, Kathmandu, Nepal, 2014.

[27] WWF Nepal, Hariyo Ban Program: Learning Strategy, September 2013, WWF Nepal, Kathmandu, Nepal, 2013.

[28] J. Chave, C. Andalo, S. Brown et al., "Tree allometry and improved estimation of carbon stocks and balance in tropical forests," Oecologia, vol. 145, no. 1, pp. 87-99, 2005.

[29] Q. M. Ketterings, R. Coe, M. Van Noordwijk, Y. Ambagau, and C. A. Palm, "Reducing uncertainty in the use of allometric biomass equations for predicting above-ground tree biomass in mixed secondary forests," Forest Ecology and Management, vol. 146, no. 1-3, pp. 199-209, 2001.

[30] IPCC, Good Practice Guidance for Land Use, Land Use Change and Forestry, IPCC, Hayama, Japan, 2013.

[31] K. G. MacDicken, A Guide to Monitoring Carbon Storage in Forestry and Agroforestry Projects, Winrock International Institute for Agricultural Development, Morrilton, AR, USA, 1997.

[32] E. R. Sharma and T. Pukkala, Volume Equations and Biomass Prediction of Forest Trees of Nepal, Forest Survey and Statistics Divison, Kathmandu, Nepal, 1990.

[33] A. N. Chaturvedi and L. Khanna, Forest Mensuration, 9, International Book Distributors, Dehra Dun, India, 1982.

[34] R. P. Sharma, "Allometric models for total-tree and component-tree biomass of alnusnepalensis $\mathrm{d}$. don in Nepal," The Indian Forester, vol. 137, no. 12, pp. 1386-1390, 2011.

[35] B. M. Shrestha and B. R. Singh, "Soil and vegetation carbon pools in a mountainous watershed of Nepal," Nutrient Cycling in Agroecosystems, vol. 81, no. 2, pp. 179-191, 2008.

[36] W. L. Gaines, J. R. Harrod, and J. F. Lehmkuhl, Monitoring Biodiversity: Quantification and Interpretation, USDA Forest Service, Washington, DC, USA, 1999.

[37] J. Bouma, H. W. G. Booltink, and P. A. Finke, "Use of soil survey data for modeling solute transport in the vadose zone," Journal of Environmental Quality, vol. 25, no. 3, pp. 519-526, 1996.

[38] J. C. Fox, P. K. Ades, and H. Bi, "Stochastic structure and individual-tree growth models," Forest Ecology and Management, vol. 154, no. 1, pp. 261-276, 2001.

[39] E. A. Freeman and G. G. Moisen, "Evaluating kriging as a tool to improve moderate resolution maps of forest biomass," Environmental Monitoring and Assessment, vol. 128, no. 1-3, pp. 395-410, 2007.

[40] S. L. King, A. J. Lister, and M. Hoppus, "A compare of kriging and cokriging for mapping forest volume in Connecticut," in Proceedings of the 12th Southern Forestry and Natural Resource Management GIS Conference, W. G. Hubbard and J. B. Jorden, Eds., , Athens, GA, USA, October 2000.

[41] C. S. A. Wallace, J. M. Watts, and S. R. Yool, "Characterizing the spatial structure of vegetation communities in the mojave desert using geostatistical techniques," Computers \& Geosciences, vol. 26, no. 4, pp. 397-410, 2000.

[42] R. Webster and M. A. Oliver, "Optimal interpolation and isarithmic mapping of soil properties: VI disjunctive kriging and mapping the conditional porbability," Journal of Soil Science, vol. 40, no. 3, pp. 497-512, 1989.

[43] S. E. Ahmed and R. M. Ewers, "Spatial pattern of standing timber value across the Brazilian amazon," PLoS One, vol. 7, no. 5, Article ID e36099, 2012.

[44] P. E. Barni and P. M. Graça, "Simulating deforestation and carbon loss in amazonia: impacts in Brazil's roraima state from reconstructing highway BR-319 (manaus-porto velho)," Environmental Management, vol. 55, no. 2, pp. 259-278, 2015. 
[45] F. L. Benítez, L. O. Anderson, and A. R. Formaggio, "Evaluation of geostatistical techniques to estimate the spatial distribution of aboveground biomass in the amazon rainforest using high-resolution remote sensing data," Acta Amazonica, vol. 46, no. 2, pp. 151-160, 2016.

[46] A. L. Pelissari, A. Figueiredo Filho, S. Péllico Netto, A. A. Ebling, M. Roveda, and C. R. Sanquetta, "Geostatistical modeling applied to spatiotemporal dynamics of successional tree species groups in a natural mixed tropical forest," Ecological Indicators, vol. 78, pp. 1-7, 2017.

[47] W. Xiang, J. Zhou, S. Ouyang et al., "Species-specific and general allometric equations for estimating tree biomass components of subtropical forests in southern China," European Journal of Forest Research, vol. 135, no. 5, pp. 963-979, 2016.

[48] Y. Zhao, Y. Ding, X. Hou, F. Y. Li, W. Han, and X. Yun, "Effects of temperature and grazing on soil organic carbon storage in grasslands along the eurasian steppe eastern transect," PLoS One, vol. 12, no. 10, pp. 1-16, 2017.

[49] R. A. Mandal, I. C. Dutta, P. K. Jha, and S. Karmacharya, "Relationship between carbon stock and plant biodiversity in collaborative forests in Terai, Nepal," International Scholarly Research Notices, vol. 2013, Article ID 625767, 7 pages, 2013.

[50] WWF Nepal Program, Ecoregion-based conservation in the eastern himalaya: Identifying Important Areas for Biodiversity Conservation, WWF Nepal Program, Kathmandu, Nepal, 2001.

[51] Y. K. Karna, "Mapping above ground carbon using world view satellite image and lidar data in relationship with tree diversity and forests," M.S. thesis, University of Twente, Enschede, Netherlands, 2012.

[52] DFRS, Tarai forests of Nepal: forests resource assessment Nepal project, Department of Forest Research and Survey, Kathmandu, Nepal, 2014.

[53] DFRS, State of Nepal's Forests, Department of Forest Research and Survey Centre, Kathmandu, Nepal, 2015.

[54] Forest Resource Assessment, Terai Forests of Nepal, Forest Resource Assessment, Kathmandu, Nepal, 2014.

[55] R. Baishya, S. K. Barik, and K. Upadhaya, "Distribution pattern of aboveground biomass in natural and plantation forests of humid tropics in northeast India," Tropical Ecology, vol. 50, pp. 295-304, 2009.

[56] M. N. K. Djuikouo, J.-L. Doucet, C. K. Nguembou, S. L. Lewis, and B. Sonké, "Diversity and aboveground biomass in three tropical forest types in the dja biosphere reserve, Cameroon," African Journal of Ecology, vol. 48, no. 4, pp. 1053-1063, 2010.

[57] K. R. Kirby and C. Potvin, "Variation in carbon storage among tree species: implications for the management of a small-scale carbon sink project," Forest Ecology and Management, vol. 246, no. 2, pp. 208-221, 2007.

[58] I. Thompson, B. Mackey, S. McNulty, and A. Mosseler, Forest Resilience, Biodiversity and Climate Change: A Synthesis of the Biodiversity/Resilience/Stability Relationship in Forest Ecosystems, United Nations Environment Programme, Montreal, Canada, 2009. 